\title{
Current Management of Hypothermia: From Theory to Application
}

\author{
Hipotermi güncel yaklaşımı: Teoriden uygulamaya
}

Ersin Demirer, ${ }_{1}^{1}$ Christian Ghattas, ${ }^{2}$ Hossam Abdel Rahman, ${ }^{3}$ Elamin Elamin ${ }^{4}$

\begin{abstract}
Objectives: To systematically review the literature on the current data in managing accidental hypothermia victims in the pre-hospital and hospital settings. Methods: We identified studies published from 1 January 1977 through 31 May 2012 by searching the MEDLINE, EMBASE and CINAHL and database of the National Library of Medicine. Initial search terms were 'definition of hypothermia', 'prehospital management', 'hospital management', and 'rewarming techniques'. Findings: Accidental hypothermia occurs due to body heat redistribution between core and peripheral tissues as well as imbalance between heat loss and production. Hypothermia may develop within a few minutes after immersion in cold water or exposure to cold weather. The prognosis in accidental hypothermia depends to great extent on the degree and duration of the hypothermia, patient's premorbid condition, and the degree of exhaustion and metabolic derangement that result from the physiologic attempts to compensate for the heat loss. Interpretations and implications: Management of deep hypothermia require rapid internal re-warming in order to support body core organs but all possible precautions should be undertaken to minimize the risk of "rewarming shock". Such care require a medical team with very well understanding of the pathophysiologic that accompanied hypothermia and the implications of various treatment strategies.
\end{abstract}

Key words: hypothermia, prehospital management, hospital management, rewarming techniques.

\section{Özet}

Amaç: Kaza ile ortaya çıkmış olan hipoterminin kurbanlarına hastane öncesi ve hastane ortamındaki yaklaşımı güncel bilgiler eşliğinde sistemli bir şekilde gözden geçirmek. Metodlar: 1 Ocak 1977 ile 31 Mayıs 2012 tarihleri arasında yayınlanmış olan çalışmaları MEDLINE, EMBASE, CINAHL ve Ulusal Tıp Kütüphanesi veritabanlarını kullanarak araştırdık. Başlangıç arama kelimeleri olarak 'hipotermi tanımı', 'hastane öncesi yaklaşım', 'hastane yaklaşımı', ve 'yeniden ısıtma teknikleri' olarak belirlendi. Bulgular: Kaza ile ortaya çıkan hipotermi kor ve perifer dokulardaki vücut ısısının yeniden dağılımı nedeni ile oluşabileceği gibi ısı kaybı ve üretimi arasındaki dengesizlikten de kaynaklanır. Hipotermi, soğuk su içerisinde bulunduktan veya soğuk havaya maruz kalındıktan birkaç dakika içerisinde gelişebilir. Kaza ile ortaya çıkan hipoterminin prognozu büyük oranda hipoterminin derecesine ve süresine, hastaların eşlik eden durumlarına, bitkinlik derecesine ve ısı kaybını telafi etmek için fizyolojik girişimlerden dolayı oluşan metabolik bozukluklara bağlıdır. Yorumlar ve Etkiler: Derin hipotermiye yaklaşım vücut kor organlarının desteklenmesi için hızlı internal yeniden ısıtma gerektirmekte iken "yeniden ısıtma şoku" riskini azaltmak için tüm önlemler alınmalıdır. Bu bakım, hipotermiye eşlik eden ve değişik tedavi strateji mekanizmalarını kullanabilen bir tıbbi ekip gerektirmektedir.

Anahtar Sözcükler: hipotermi, hastane öncesi yaklaşım, hastane yaklaşımı, yeniden ısıtma teknikleri.

${ }^{1}$ GATA Haydarpaşa Eğitim Hastanesi, Göğüs Hastalıkları Servisi, İstanbul

${ }^{2}$ Saint Elizabeth Sağlık Merkezi, İç Hastalıkları Servisi, Ohio, $A B D$

${ }^{3}$ Uluslararası Tıp Merkezi, Anestezi Servisi, Kahire, Mısır

${ }^{4}$ South Florida Üniversitesi, Göğüs Hastalıkları, Yoğun Bakım ve Uyku Servisi, Florida, ABD

Submitted (Başvuru tarihi): 09.05.2012 Accepted (Kabul tarihi): 22.07.2012

Correspondence (iletişim): Ersin Demirer, Department of Pulmonary Diseases, GMMA Haydarpaşa Training Hospital, İstanbul, Turkey

e-mail: drersin73@yahoo.com 


\section{Review Criteria}

Search strategy

The following electronic databases were searched (1 January 1977 through 31 May 2012): Cochrane Central Register of Controlled Trials, MEDLINE, EMBASE and CINAHL. Reference lists of previous reviews, and both relevant and possible relevant studies identified from the searches, were checked.

Identification of studies

Citations were checked, with respect to the inclusion criteria by all reviewers.

\section{Assessment of methodological quality}

Included studies were assessed for possible sources of bias as recommended by the UK Cochrane Center however no specific 'quality' scale was used.

\section{Message for the Clinic:}

1. Speedy and effective revival of the hypothermia victims depends on a well orchestrated management strategy both at the pre- and in-hospital levels.

2. For deep hypothermia, rapid internal rewarming in needed in order to support body core organs.

3. All achievable precautions should be undertaken to minimize the risk of "rewarming shock".

4. For lesser degrees of hypothermia, recoverability depends more on the adequacy of hospital supportive care by well trained medical team, rather than on the method of rewarming.

Severe accidental hypothermia (body temperature below $30^{\circ} \mathrm{C}$ ) is associated with marked depression of cerebral blood flow and oxygen requirement, in addition to reduced cardiac output, and decreased arterial pressure. Most clinically significant incidences of hypothermia result from a traumatic injury in a colder environment followed by a prolonged exposure without adequate protective clothing. Such effect is more pronounced after cold water submersion since it can cool the core body temperature much more rapidly than exposure to cold air (1).

On the other hand, hypothermia also can occur in relatively warm water conditions if exposure is long enough and if core temperature loss is increased by recent ingestion of alcohol or concurrent illnesses. The later may includes severe sepsis especially in the elderly, hypothyroidism, hypopituitarism, hypoadrenalism, head injury, drug ingestion, and diabetes (1-3) (Table 1).

Table 1: Common causes of hypothermia

\begin{tabular}{|c|c|}
\hline $\begin{array}{l}\text { - Dermal disease } \\
\text { Burns } \\
\text { Exfoliative dermatitis } \\
\text { Severe psoriasis }\end{array}$ & $\begin{array}{l}\text { - Metabolic } \\
\text { Hypoadrenalism } \\
\text { Hypopituitarism } \\
\text { Hypothyroidism }\end{array}$ \\
\hline $\begin{array}{l}\text { - Drug induced } \\
\text { Ethanol } \\
\text { Phenothiazines } \\
\text { Sedative-hypnotics }\end{array}$ & $\begin{array}{l}\text { - Neurologic } \\
\text { Acute spinal cord } \\
\text { transection } \\
\text { Head trauma } \\
\text { Stroke } \\
\text { Tumor } \\
\text { Wernicke's disease }\end{array}$ \\
\hline $\begin{array}{l}\text { - Environmental } \\
\text { Imersion } \\
\text { Nonimmersion }\end{array}$ & $\begin{array}{l}\text {-Neuromuscular ineffi- } \\
\text { ciency } \\
\text { Age extreme } \\
\text { Impaired shivering } \\
\text { Lack of acclimatization }\end{array}$ \\
\hline $\begin{array}{l}\text { - Iatrogenic } \\
\text { Aggressive fluid } \\
\text { resuscitation } \\
\text { Heat stroke treatment }\end{array}$ & - Sepsis \\
\hline
\end{tabular}

This review aims to illustrate the deleterious effects of hypothermia on the various body systems and the impact of appropriate pre-hospital and in-hospital management on the patients' outcome.

\section{Pathophysiological \& Clinical Features}

Hypothermia can produce profound and widespread physiological changes with diverse pathological manifestations; however many of these changes can be reversible on rewarming. As core body temperature declines ice crystals begin to form within both extraand intracellular. This is followed with gradual but progressive decline in the body metabolic rate and consequently oxygen consumption $(3,4)$. In the meantime as the body cells become dehydrated, they shrink with alteration of blood flow to the exposed areas, increase intracellular salt concentration and ultimately tissue distraction. Now, with thawing, further damage may ensue as showers of emboli spread through the microvasculature. It is noteworthy to remember that not all tissue components freeze and then thaw at the 
same time and rate, explaining the variability of hypothermia presentation.

Clinically, mild hypothermia $\left(34\right.$ to $<36^{\circ} \mathrm{C}$ ) results in shivering, loss of fine motor coordination, lethargy and mild confusion (3-8). While in moderate $\left(30^{\circ} \mathrm{C}\right.$ to $34^{\circ} \mathrm{C}$ ) to severe hypothermia (below $30^{\circ} \mathrm{C}$ ), the pupils may dilate, and cardiovascular activity may stop (Table 2).

Table 2: Key clinical findings at different degrees of hypothermia*

- Normal oral temperature $\left(37^{\circ} \mathrm{C}\right)$ :

- Early hypothermia $\left(35-37^{\circ} \mathrm{C}\right)$ :

o Shivering

o Increase metabolic rate

- Cool cyanotic extremities

o Tachycardia and impaired judgment

- Mild hypothermia $\left(33-35^{\circ} \mathrm{C}\right)$ :

o Confusion

o Disorientation

o Hyperventilation

- Moderate hypothermia: $\left(30-33^{\circ} \mathrm{C}\right)$ :

o Shivering ceases

o Amnesia

o Lethargy

o "J-wave"

o Atrial fibrillation

- Pupils dilate

o Severe hypotension

- Severe hypothermia: $\left(27-30^{\circ} \mathrm{C}\right)$ :

o Slowing of pulse/respiration

o Increased muscle rigidity

- Loss of consciousness

o Ventricular fibrillation

- Fulminate hypothermia $\left(<27^{\circ} \mathrm{C}\right)$ :

o Loss of deep tendon. skin and capillary reflexes

- Patients appear clinically dead

o Complete cardiac standstill

${ }^{*}$ As documented by low-registering thermometer.

Victims who have experienced near-drowning prior to becoming hypothermic may even aspirate water and have further pulmonary damage, resulting in a much more difficult postresuscitative course. Since laryngospasm without aspiration of water may accompany near-drowning episodes, hypoxia can occur without significant pulmonary insult from aspirated water. On the other hand, aspiration of salt and fresh water can results in substantial damage to the pulmonary system. Acute lung injury (ALI) is a common manifestation of near-drowning experience. Depending on the extent of pulmonary and systemic involvement, the neardrowning trauma victim is at increase risk of progression to acute respiratory distress syndrome.

Various body thermoregulatory vasoconstriction mechanisms help to preserve the core temperature by preventing cooling of blood in extremities that subsequently returns to the core. However, with a significant drop in core temperature, the unconscious hypothermic patient may appear clinically dead (without palpable pulse. blood pressure or respiration) but may still be successfully resuscitated with little or no neurological squeals if proper and aggressive management is instituted. Fully successful clinical recovery was reported after accidental hypothermia with an initial core temperature of $15.2^{\circ} \mathrm{C}$ following submersion under water for 66 minutes and in others similar accidental hypothermia $(4,9,10)$.

Hemodynamically, mild hypothermia $\left(34^{\circ} \mathrm{C}\right.$ to $\left.35^{\circ} \mathrm{C}\right)$ causes an increase in pulse rate, peripheral vascular resistance, blood pressure, central venous pressure, and cardiac output. While, moderate $\left(30^{\circ} \mathrm{C}\right.$ to $\left.34^{\circ} \mathrm{C}\right)$ and severe hypothermia (below $30^{\circ} \mathrm{C}$ ) can lead to bradycardia, various atrial/junctional or ventricular arrhythmias, hypotension, and eventually a fall in cardiac output. As the temperature drops below $30^{\circ} \mathrm{C}$, the risk of ventricular fibrillation (VF) and ultimately asystole dramatically increases. The Osborn wave (also referred to as "the J wave," "the J deflection," or "the camel's hump") is a distinctive deflection occurring at the QRS-ST junction most prominently in lead V3 or V4, in approximately $80 \%$ of hypothermic patients (core body temperature $\leq 95$ degrees. Generally, the amplitude and duration of Osborn waves are inversely related to core temperature. However, the Osborn wave is not pathognomonic of hypothermia as it may 
also be seen with sepsis and central nervous system lesions $(11,12)$.

Oxygenation and acid-base balance also can be altered by hypothermia, with the initial manifestation of mild hypothermia $\left(34^{\circ} \mathrm{C}\right.$ or higher) being hyperventilation. However, as the core temperature decreases, there is more tendency for respiratory depression with subsequent hypoxemia and hypercarbia. A combined respiratory and metabolic acidosis may occur due to hypoventilation, carbon dioxide retention, reduced hepatic metabolism of organic acid secondary to hepatic hypoperfusion, and increased lactic acid production from impaired perfusion of skeletal muscle and shivering $(3,8,13)$. There is still some controversy about whether arterial blood gases should be corrected for temperature in the hypothermic patient, although rewarming usually can be expected to correct the metabolic imbalance after the normal circulation is reestablished $(5,13,14)$. On the other hand, metabolic acidosis secondary to hypothermia is usually due to alteration of blood flow to the exposed areas and tissue distraction and may not respond to bicarbonate treatment $(3,4,15)$.

Finally, since hypothermia affects the function of all organ systems it can hinder the release of antidiuretic hormone in addition to the oxidative ability of renal tubules, causing diuresis and volume depletion $(4,16)$. In addition as the core temperature falls below $27^{\circ} \mathrm{C}$ the ensuing generalized dehydration and splenic contraction lead to elevation of both serum hematocrit and plasma viscosity increasing the chance for developing deep venous thrombosis (4). On the other hand, hypothermic victims may develop hyperglycemia secondary to decreased insulin release and inhibition of peripheral utilization of glucose. This condition often will be reversed with rewarming, although the use of insulin rarely may be necessary in some cases (17). However, prolonged shivering may completely deplete body glycogen stores and ultimately lead to hypoglycemia. Hypoglycemia also may be an initial laboratory finding in patients who have been exposed to long-lasting physical endurance and exhaustion and often can be noted in alcoholic patients, who already may have depleted glycogen stores $(18,19)$.
Another worrisome complication of shivering is progressive rhabdomyolysis as it can further worsen the ongoing metabolic acidosis and renal failure.

\section{General Principles of Treatment}

\section{Prehospital Management}

Early recognition of hypothermia by all emergency personnel is essential to maximize survival and reduce further complications. Emergency health care providers in areas where cold weather emergencies exist must also be trained to use low-register thermometers (tympanic or rectal probes) and appropriate rewarming equipment. Both basic life support and advanced cardiac life support (ACLS) should be appropriately instituted as soon as feasible. However, it is imperative to remember that increasing body temperature by aggressive external rewarming techniques before CPR is under way will only increase the metabolic demands of the body without any accompanying increase in blood supply. This is in turn will increase the chances of tissues infarction or even gangrene. Wet garments should be removed carefully and replaced with dry (preferably warm) garments $(4,20)$. Blankets and/or an insulated sleeping bag may be used to retain body heat, and efforts should be made to shield the victim from wind chill. Whenever possible, cold sleeping bags should be prewarmed with a volunteer prior to placing a victim inside.

Airway treatments with portable units that can deliver warm, humidified air/oxygen heated to $42-46^{\circ} \mathrm{C}$ can be used to donate heat back to the core and improve the patient's heat balance (21). Exercise is not recommended as a rewarming strategy (unless core temperature is above $35^{\circ} \mathrm{C}$ ) that is to prevent fatal arrhythmias secondary to peripheral vasodilation with further hypotension as well as causing cool blood to return to the central circulation (22). The later is different from "Afterdrop" which is a drop in core temperature after resuscitation efforts have begun, secondary to significant heat conduction from the core of the body to more peripheral layers which have not been rewarmed (23).

ECG monitoring should be performed in the prehospital setting whenever possible during resusci- 
tation and transport. However, prehospital personnel also should be aware that in patients with moderateto-severe hypothermia adhesive pads for monitor leads will not stick to cold skin, and conduction of electrical signals across cold skin may be impaired. In such incidents, insertion of needle electrodes may be of benefit. The needle may be an injection needle punctured through the gel-foam of a conventional adhesive pad which is then in turn, connected to the ECG electrode of the monitor. This method avoids the need to have specially-made needle electrodes for each machine. However, if still no QRS complexes are seen on the initial ECG, the tracing amplitude should be maximally amplified.

\section{Movement}

Because the cold heart is irritable and susceptible to serious arrhythmias (such as VF), all patients with a pulse should be moved gently during transportation or during transfer of the patient from a stretcher to a hospital bed. The patient ideally should have vital signs, core temperature, and cardiac rhythm monitored continuously during transportation, and equipment for resuscitation (including a defibrillator) should be readily available. Whenever possible, a horizontal position should be maintained during movement in order to minimize any potential orthostatic blood pressure drop due to cold-induced cardiovascular reflex impairment.

\section{Interventions}

It is important to stress that the severely hypothermic heart $\left(<30^{\circ} \mathrm{C}\right)$ is usually unresponsive to cardioactive drugs, pacemaker stimulation, and defibrillation (4). Various administered medications, including epinephrine, lidocaine, and procainamide, can accumulate to toxic levels if used repeatedly in the severely hypothermic victim. Nonessential interventions should be avoided until the core temperature is increased to above $30^{\circ} \mathrm{C}$. However, indicated and necessary procedures (e.g. CPR, endotracheal intubation/ventilation, treatment of significant wounds and injuries) should never be withheld. Prior ventilation with 100\% oxygen may lessen the likelihood of VF when invasive procedures are attempted $(24,25)$.
Prehospital emergency care providers should be aware that drugs for prehospital use must be prevented from freezing, as this may affect their therapeutic strength after thawing. Most drugs can be stored safely at $15^{\circ} \mathrm{C}$ to $30^{\circ} \mathrm{C}$, and heated drug boxes may be needed for prehospital resuscitations in which ambient temperatures fall in the low range.

Drugs pertinent for resuscitation also may be needed in the lowest known effective dose that can be tried, especially with sluggish renal functions. Even though, there are no specific recommendations on withholding or changing the interval of medication administration, doubling the usual recommended time between doses might be prudent.

Cardiac monitoring and IV access should be established rapidly if possible, but should not delay transport. Endotracheal intubation to provide effective ventilation with warm, humidified oxygen and to prevent aspiration should be performed in all unconscious hypothermic patients with inadequate ventilation. In such cases, prior ventilation with $100 \%$ oxygen through a bag-valve mask is recommended. In a prospective multicenter study of hypothermia victims, careful endotracheal intubation did not result in a single incident of VF (26).

If the hypothermic victim is in cardiac arrest, follow the hypothermic treatment algorithm. If VF is detected, emergency personnel should deliver three shocks to determine fibrillation responsiveness (including the use of automated external defibrillators). If VF persists after three shocks, further shocks should be avoided until after rewarming to above $30^{\circ} \mathrm{C}$. CPR, rewarming, and rapid transport should immediately follow the initial three defibrillations. If core temperature is below $30^{\circ} \mathrm{C}$, successful defibrillation may not be possible until rewarming is accomplished (4).

Volume depletion is a common clinical finding in the severely hypothermic patient, and IV fluids are indicated. The usual parameters for fluid assessment may be difficult to use in a hypothermic victim, due to large quantities of fluid in the "third space" and the clinical difficulty of obtaining orthostatic blood pressures and weight. It should be emphasized that peripheral access may be quite limited due to vasocon- 
striction, and a central venous line may need to be placed upon arrival in the ED. Standard IV infusion of saline and dextrose solutions can be used safely after thawing if no visible precipitates are present and the bags are intact.

In addition, all efforts should be taken to warm infused IV fluids prior to administration. A target temperature of approximately $43^{\circ} \mathrm{C}$ will prevent any further core temperature drop. Methods to warm fluids include using standard blood warmers adapted for saline bag use or portable battery, operated IV line warmers, preheating saline IV bags and storing them in heated carrying packs, and micro waving liter bags of saline with insulation during administration. The use of an insulation barrier around all IV tubing and solutions can help prevent heat loss from warmed solutions in cold environments.

Other rewarming methods includes the use of hot packs, which a simple, inexpensive intervention was shown to be as effective IV fluid warming to maintain thermostasis and further studies on hypothermic trauma patients are warranted (27).

\section{Hospital Management}

Treatment of severely hypothermic victims in cardiac arrest in the hospital setting should be directed at rapid core rewarming. Additionally, trauma should be sought and treated in hypothermic victims, as injured patients with core temperatures less than $32^{\circ} \mathrm{C}$ are likelier to die than those with normal temperatures (28).

Although esophageal temperature is a good indicator of heart temperature, most EDs use tympanic membrane or rectal temperatures (25). However it should be noted that using tympanic devices in patients with cerumen-blocked external canals or placing rectal probes in frozen feces will not be effective due to the inability to obtain an accurate reading (5).

\section{Laboratory Tests}

When possible, routine laboratory evaluation should be accomplished, including arterial blood gases (ABGs), a complete blood count, prothrombin time, partial thromboplastin time, glucose, electrolytes, blood urea nitrogen, serum creatinine, amylase, liver function tests, ECG, chest radiography; and urinalysis. In addition, when appropriate, blood or urine toxic agents screening should be performed. These tests will allow a baseline to be established and will be most useful in the post-resuscitative period when complications can occur. There is general agreement that ABGs need not be corrected during the hypothermic phase, as rewarming will correct all hypothermicinduced alterations.

\section{Rewarming}

Rewarming remains the primary treatment in severe hypothermia for any abnormalities detected. The faster the patient is warmed, the better the prognosis. Hence, all efforts should be directed toward reducing further heat loss and rewarming the victim. There are three options for rewaming: (1) passive rewarming, (2) active external rewaming and (3) active internal rewaming. The overall condition of the patient and the core body temperature on presentation, will determine the most appropriate rewaming method.

\section{Mild Hypothermia $\left(34^{\circ} \mathrm{C}\right.$ to $\left.35^{\circ} \mathrm{C}\right)$}

Patients with mild hypothermia $\left(34^{\circ} \mathrm{C}\right.$ or above) generally have a good prognosis regardless of the rewarming method used $(4,8)$. The victim wet clothing should be removed carefully, and the patient should be insulated and protected from wind chill, if indicated In the conscious patient, external rewarming is appropriate, either passively by using blankets or actively using hot water bottles, warm baths, or chemical heat packs placed under the arms and on the neck, chest, and groin.

Warm circulating air systems provide for additional heat exchange by convection and may prove to be quite effective. These methods can allow the patient to warm at a rate of $0.5^{\circ} \mathrm{C}$ to $1^{\circ} \mathrm{C}$ per hour. Although quite effective, warm baths have the disadvantage of not allowing the cardiac rhythm to be monitored. Again, the patient should be cautioned not to exercise as a method of rewarming because of the potential for cardiovascular collapse. In any case the overall prognosis is usually quite good. 


\section{Moderate Hypothermia $\left(30^{\circ} \mathrm{C}\right.$ to $\left.33.9^{\circ} \mathrm{C}\right)$}

Hospital treatment of moderate hypothermia should include all the basic measures listed above. CPR should be initiated promptly if the patient is in cardiac arrest, although pulse and ventilations may need to be checked for longer periods of time to detect minimal cardiopulmonary efforts. A maximum of 45 seconds should be adequate time to confirm pulselessness or profound bradycardia for which CPR would be required $(24,25)$. Loss of pupil reflexes, hyporeflexia, absent blood pressure, and lack of response to painful stimuli may not indicate clinical death in the hypothermic patient. A routine search for external trauma should be accomplished by hospital personnel, and treatment should be initiated (e.g., pressure dressings, etc.). Obvious physical evidence of death would strongly argue against beginning any resuscitation (e.g., gross evisceration, decomposition, decapitation). Stiffness of the victim's body, which can be caused by hypothermia, should not be confused with classic rigor mortis.

Attempts at application of external rewarming to patients with moderate hypothermia can be quite hazardous. Such interventions might cause sudden peripheral vasodilation and allow cold, lactic acid-rich blood to return to the core with a subsequent convective afterdrop in core temperature and $\mathrm{pH}$, increasing the likelihood of VE $(4,21,23)$.

Minimizing convective afterdrop is accomplished by passive rewarming and stabilization methods (covering with blankets, blocking exposure to wind, and removing wet garments). Most afterdrops occur during the first few minutes of treatment, and rewarming efforts in this group of hypothermic victims should be directed to the core (warm humidified oxygen or air; warmed IV fluids). Patients who are conscious and have an effective circulation also may be treated with external rewarming to truncal areas only, but constant monitoring must be maintained to detect any afterdrop events.

\section{Severe Hypothermia $\left(<30^{\circ} \mathrm{C}\right)$}

Although the ability to treat severely hypothermic victims in the prehospital setting will vary depending on the equipment available to prehospital personnel, most resuscitative efforts should be directed to performing CPR in cardiac arrest victims and transporting them to a hospital setting where definitive rewarming can take place.

Techniques that can be used for rapid core rewarming include the administration of heated, humidified oxygen $\left(42^{\circ} \mathrm{C}\right.$ to $46^{\circ} \mathrm{C}$ ), warmed $\left(43^{\circ} \mathrm{C}\right)$ IV fluids (normal saline) infused centrally at rates of approximately 150 to $200 \mathrm{~mL} / \mathrm{hr}$ (however avoid pulmonary edema secondary to vigorous rehydration), peritoneal lavage with warmed $\left(43^{\circ} \mathrm{C}\right)$ potassium-free dialysate administered two liters at a time (no dwell time), and/or extra-corporeal blood warming with partial bypass $(4,5,20,25)$.

The use of esophageal rewarming tubes has not been reported in the United States but they have been utilized extensively in Europe especially in hospitals without extra-corporeal rewarming equipment (29). Pleural lavage with warm saline instilled through a chest tube also has been used successfully to increase core temperature as much as $2.5^{\circ} \mathrm{C}$ per hour but has the major disadvantages of possible infection, bleeding, and the requirement for large volumes of fluid $(26,29)$. Arterial and venous catheters have been utilized to create a circulatory fistula through which the blood is heated by a modified commercially available countercurrent fluid warmer, thus achieving a more simplified extracorporeal rewarming method (30). Heparin-free systems are available which may prevent aggravation of coagulopathies seen in hypothermic patients (31). Extra-corporeal rewarming (ECR) has long been used to rewarm victims of accidental deep hypothermia. Unlike other rewarming techniques, it has the advantage of restoring organ perfusion quickly in patients with inadequate circulation. Multiple studies evaluated the short and long-term outcomes of survivors of accidental deep hypothermia with circulatory arrest who had been rewarmed with ECR. Overall, the clinical experience demonstrates that young, otherwise healthy hypothermic victims who were treated with ECR can survive accidental deep hypothermia with no or minimal cerebral impairment, even after prolonged circulatory arrest (32-34). In addition, radio frequency rewarming is continued to 
evolve as a possible method for rapid core rewarming (35). Continuous core temperature and cardiac monitoring should be performed, as well as placing a urinary catheter to monitor urine output. Pulse oximeters do not work well in vasoconstricted hypothermic patients and most likely will not accurately reflect oxygenation (5).

Postresuscitative complications may include pneumonia, pulmonary edema, atrial arrhythmias, acute tubular necrosis, acute pancreatitis, limbs compartment syndromes, disseminated intravascular coagulation, hypophosphatemia, hemolysis, intravascular thrombosis, myoglobinuria, seizures, and temporary adrenal insufficiency $(4,5,36)$.

Severe accidental hypothermia is a serious complication of elevated blood alcohol levels and elicits drug use $(37,38)$. In rural areas, over $90 \%$ of hypothermic deaths are associated with excessive alcohol consumption (39).

\section{Terminating Resuscitative Efforts}

Some clinicians believe that patients who appear dead after prolonged exposure to cold temperatures should not be considered dead until core temperatures are near normal and CPR still elicits no response. If drowning preceded the victim's hypothermia, successful resuscitation may be more unlikely. Hypothermic victims should be treated aggressively, because even when all vital signs are absent, survival without neurological impairment may be possible in certain patients even when serum potassium is elevated (40).

However, the old clinical maxim that no one is presumed dead until they have been rewarmed to near normal temperatures can not be applied literally in all cases. Rewarming efforts, in general, probably should be continued until core temperature is at least $32^{\circ} \mathrm{C}$ and may be discontinued if the patient continues to show no effective cardiac rhythm and remains totally unresponsive to all treatment. However, the decision to terminate resuscitation must be individualized by the physician in charge and should be based on the unique circumstances of each incident.

\section{Conclusion}

Successful treatment of hypothermia in the prehospital and hospital setting, require the use of CPR, removing wet clothing and sheltering from wind chill, and stabilization with warmed air/oxygen and IV fluids. In addition, successful initial treatments modalities require optimal training of emergency personnel and appropriate ACLS resuscitation methods at each institution. Further more the utilization of hypothermia treatment algorithm can facilitate the teaching of basic assessment and rewarming techniques to all health care providers. Because severe hypothermia is frequently preceded by other disorders (e.g., drug overdose, alcohol use, trauma, etc.), the clinician must seek and treat these underlying conditions while simultaneously treating the hypothermia.

\section{CONFLICTS OF INTEREST}

None declared.

\section{REFERENCES}

1. Robinson JL, Jou H, Spady DW. Accuracy of parents in measuring body temperature with a tympanic thermometer. BMC Fam Pract 2005; 11:6-3.

2. Goldman A, Exton-Smith AN, Francis G, O'Brien A. A pilot study of low body temperatures in old people admitted to hospital. J R Coll Physicians Lond 1977; 11:291-306.

3. Mallet ML. Pathophysiology of accidental hypothermia. QJM 2002; 95:775-85. [CrossRef]

4. Kempainen RR, Brunette DD. The evaluation and management of accidental hypothermia. Respir Care 2004; 49:192-205.

5. Schneider SM. Hypothermia. From recognition to rewarming. Emergency Medicine Reports 1992; 13:I-20.

6. Mair P, Kornberger E, Furtwaengler W, Balogh D, Antretter $\mathrm{H}$. Prognostic markers in patients with severe accidental hypothermia and cardiocirculatory arrest. Resuscitation 1994; 27:47-54. [CrossRef]

7. White JD. Hypothermia: The Bellevue experience. Ann Emerg Med 1982; 11:417-24.

8. Wu X, Stezoski J, Safar P, Nozari A, Tisherman SA. After spontaneous hypothermia during hemorrhagic shock, 
continuing mild hypothermia (34 degrees C) improves early but not late survival in rats. J Trauma 2003; 55:308-16.

9. Bolte RG, Black PG, Bowers RS, Thorne JK, Corneli HM. The use of extracorporeal rewarming in a child submerged for 66 minutes. JAMA 1988; 260:377-9. [CrossRef]

10. Walpoth $\mathrm{BH}$, Locher $T$, Leupi $F$, Schüpbach $P$, Mühlemann W, Althaus U. Accidental deep hypothermia with cardiopulmonary arrest: extracorporeal blood rewarming in 11 patients. Eur J Cardiothorac Surg 1990; 4:390-3. [CrossRef]

11. Patel A, Getsos JP, Moussa G, Damato AN. The Osborn wave of hypothermia in normothermic patients. Clin Cardiol 1994; 17:273-6. [CrossRef]

12. Danzl DF, Pozos S, Hamlet MP. Accidental hypothermia. In: Auerbach RS, Geehr EC, eds. Management of Wilderness and Environmental Emergencies. 2nd ed. St Louis. Missouri: Mosby, 1989: 27-63.

13. Wears RL. Blood gases in hypothermia (letter). JACEP 1979; 8:247. [CrossRef]

14. Alston TA. Blood gases and $\mathrm{pH}$ during hypothermia: the "-stats". Int Anesthesiol Clin 2004; 42:73-80. [CrossRef]

15. Koller R, Schnider TW, Neidhart P. Deep accidental hypothermia and cardiac arrest-rewarming with forced air. Acta Anaesthesiol Scand 1997; 41:1359-64. [CrossRef]

16. Tsuei BJ, Kearney PA. Hypothermia in the trauma patient. Injury 2004; 35:7-15. [CrossRef]

17. Mehta SR, Srinivasan KV, Bindra MS, Kumar MR, Lahiri AK. Near drowning in cold water. J Assoc Physicians India 2000; 48:674-6.

18. Young AJ, Sawka MN, Levine L, Burgoon PW, Latzka WA, Gonzalez RR, Pandolf KB. Metabolic and thermal adaptations from endurance training in hot or cold water. J Appl Physiol 1995; 78:793-801.

19. Bjertnaes L, Hauge A, Kjekshus J, Søyland E. Cardiovascular responses to face immersion and apnea during steady state muscle exercise. A heart catheterization study on humans. Acta Physiol Scand 1984; 120:605-12. [CrossRef]

20. Weinberg AD. Hamlet MP. Paturas JL. Cold Weather Emergencies: Principles of Patient Management. Bran- ford, Connecticut, American Medical Publishing Co. 1990, 10-30.

21. Greif R, Rajek A, Laciny S, Bastanmehr H, Sessler DI. Resistive heating is more effective than metallic-foil insulation in an experimental model of accidental hypothermia: A randomized controlled trial. Ann Emerg Med 2000; 35:337-45. [CrossRef]

22. Rajek A, Lenhardt R, Sessler DI, Brunner G, Haisjacki M, Kastner J, et al. Efficacy of two methods for reducing postbypass afterdrop. Anesthesiology 2000; 92:447-56. [CrossRef]

23. Romett TT. Mechanism of afterdrop after cold water immersion. J Appl Physiol 1988; 65:1535-8.

24. Steinman AM. Cardiopulmonary resuscitation and hypothermia. Circulation 1986; 74:IV29-32.

25. Antretter H, Dapunt OE, Bonatti J. Management of profound hypothermia. Br J Hosp Med 1995; 54:215-20.

26. Hall KN. Syverud SA. Closed thoracic cavity lavage in the treatment of severe hypothermia in human beings. Ann Emerg Med 1990; 19:204-6. [CrossRef]

27. Watts DD, Roche M, Tricarico R, Poole F, Brown JJ Jr, Colson $\mathrm{GB}$, et al. The utility of traditional prehospital interventions in maintaining thermostasis. Prehosp Emerg Care 1999; 3:115-22. [CrossRef]

28. Martin RS, Kilgo PD, Miller PR, Hoth JJ, Meredith JW, Chang MC. Injury-associated hypothermia: an analysis of the 2004 National Trauma Data Bank. Shock 2005; 24:114-8. [CrossRef]

29. Sumann G, Krismer AC, Wenzel V, Adelsmayr E, Schwarz $\mathrm{B}$, Lindner $\mathrm{KH}$, et al. Cardiopulmonary resuscitation after near drowning and hypothermia: restoration of spontaneous circulation after vasopressin. Acta Anaesthesiol Scand 2003; 47:363-5. [CrossRef]

30. Haughn C, Gallo U, Raimonde AJ, Evancho-Chapman M, Arends D, Schmidt SP, et al. Feasibility of a novel venoveno circuit as a central rewarming method in a severely hypothermic canine model. Curr Surg 2003; 60:442-8. [CrossRef]

31. Del Rossi AJ, Cernaianu AC, Vertrees RA, Fuller SJ, Costabile J, Yu Y, et al: Heparinless extracorporeal bypass for treatment of hypothermia. J Trauma 1990; 30:79-82.

32. Morita S, Inokuchi S, Yamagiwa T, Lizuka S, Yamamoto $\mathrm{R}$, Aoki $\mathrm{H}$, et al. Efficacy of portable and percutaneous 
cardiopulmonary bypass rewarming versus that of conventional internal rewarming for patients with accidental deep hypothermia. Crit Care Med 2011; 39:1064-8. [CrossRef]

33. Talbot SG, Davidson MJ, Javid S, Patel AN, Fitzgerald D, Patel V. Hypothermic cardiac arrest rescued with cardiopulmonary bypass and decompressive laparotomy. Emerg Med J 2010; 27:958-9. [CrossRef]

34. Farstad M, Andersen KS, Koller ME, Grong K, Segadal L, Husby $P$. Rewarming from accidental hypothermia by extracorporeal circulation: A retrospective study. Eur J Cardiothorac Surg 2001; 20: 58-64. [CrossRef]

35. Olsen RG. Reduced temperature afterdrop in rhesus monkeys with radio frequency rewarming. Aviat Space Environ Med 1988; 59:78-80.

36. Coskun KO, Popov AF, Schmitto JD, Hinz J, Kriebel T, Schoendube FA, et al. Extracorporeal circulation for rewarming in drowning and near-drowning pediatric patients. Artif Organs 2010; 34:1026-30. [CrossRef]
37. Bierens JJ, Uitslager $R$, Swenne-van Ingen $M M$, van Stiphout WA, Knape JT. Accidental hypothermia: incidence, risk factors and clinical course of patients admitted to hospital. Eur J Emerg Med 1995; 2:38-46. [CrossRef]

38. Vassal T, Benoit-Gonin B, Carrat F, Guidet B, Maury E, Offenstadt. Severe accidental hypothermia treated in an ICU: prognosis and outcome. Chest 2001; 120:19982003. [CrossRef]

39. Gallaher MM, Fleming DW, Berger LR, Sewell CM. Pedestrian and hypothermia deaths among Native Americans in New Mexico. Between bar and home. JAMA 1992; 267:1345-8. [CrossRef]

40. Wollenek G, Honarwar N, Golej J, Marx M. Cold water submersion and cardiac arrest in treatment of severe hypothermia with cardiopulmonary bypass. Resuscitation 2002; 52:255-63. [CrossRef] 